\title{
Fat Content and Fillet Shape of Atlantic Salmon: Relevance for Processing Yield and Quality of Raw and Smoked Products
}

\author{
T. Mørkøre ${ }^{1^{*}}$, JL. Vallet ${ }^{2}$, M. Cardinal ${ }^{2}$, MC. Gomez-Guillen ${ }^{3}$, P. Montero ${ }^{3}$, OJ. Torrissen ${ }^{4}$, \\ R. Nortvedt ${ }^{5}$, S. Sigurgisladottir ${ }^{6}$, MS. Thomassen ${ }^{1}$
}

\footnotetext{
${ }^{1}$ AKVAFORSK, Institute of Aquaculture Research Ltd., PO box 5010, N-1432 Aas, Norway

2 Laboratoire Génie Alimentaire, IFREMER, rue de l'île d'Yeu, BP 21105, 44311 Nantes cedex 3, France

${ }^{3}$ Consejo Superior de Investigacions Cientìficas, Instituto del Frio, 28040 Madrid, Spain

${ }^{4}$ Institute of Marine Research, N-5392 Storebo, Austevoll, Norway

${ }^{5}$ Institute of Nutrition, Directory of Fisheries, PO box 185 Sentrum, N-5804 Bergen, Norway

${ }^{6}$ Matra, Technological Institute of Iceland, Keldnaholt, IS-112, Reykjavik, Iceland

*: Corresponding author : Turid Morkore AKVAFORSK, Institute of Aquaculture Research Ltd.

N-1432 Aas, Norway Telephone +47 64949509 Telefax +4764949502 e-mail turid.morkore@akvaforsk.nlh.no
}

\begin{abstract}
Relevance of fat content and fillet shape of Atlantic salmon for quality and yield during smoking processing was investigated. Fat content significantly influenced quality of raw and smoked products, although the interactions varied according to the raw material used and smoking temperature. In raw and smoked fillets, increasing fat content coincided with increasing $L^{*}$ and $b^{*}$ values and decreasing fat holding capacity. In smoked salmon, fat content also correlated positively to the $a^{*}$-value, smoke-intensity-/wood-fire flavor and fatty texture, and negatively to water holding capacity and shear-force. Weight loss during salting and smoking decreased with increasing fat content, and voluminous shaped fillets gave higher yield than slim fillets.
\end{abstract}

Keywords: Atlantic salmon, fat content, fillet shape, salmon quality, processing. 


\section{Introduction}

The Norwegian production of cultured Atlantic salmon comprised about $415.000 \mathrm{mt}$ in 1999 (Fiskeridirektoratet, 1999). According to Borch and Aker (1997), 40 - 50 \% of this production is consumed as cold-smoked products. The value adding process at the smokehouses include filleting, trimming, salting and smoking of the fish. Filleting and trimming implies removal of head, bones, fins and visible fat according to customer's demands. Dry salting is the most common salting method, but also brining is widely used. Cold smoking is performed within a temperature range of $20-30{ }^{\circ} \mathrm{C}$. Maximising the yield throughout the value adding process is of major concern in order to achieve economic success. However, interactions between raw material characteristics and production yield have not been reported, except from a study with brine injected salmon fillets (Rørå and others 1998).

Important quality characteristics of salmon include fat content, fat distribution pattern, body shape, texture, colour and appearance (Gormley 1992; Koteng 1992;

Christiansen and others 1995; Borch and Aker 1997). The relative importance of anyone characteristic depends, however, on the intended use, regional preferences, consumer attitudes and methods of preservation (Haard 1992). In salmon culture, the raw material properties may be partly selected through breeding (Gjedrem 1997), and a large body of literature has also been published on the effects of feed composition and feeding routines (Lie and others 1988; Lie and Huse 1992; Shearer 1994; Torrissen and others 1995; Wathne 1995; Sheehan and others 1996; Bjerkeng and others 1997; Bell and others 1998; Hillestad and others 1998; Einen 1998). There is, however, a lack of information on the influence of the raw material composition on the quality of the final smoked product.

The aim of the present study was to investigate the relevance of fat content, visible fat deposits and fillet shape of Atlantic salmon for production yield during smoking processing, and to elucidate the interactions between fat content/ visible fat deposits and water and fat-holding capacity, colour, texture, flavour and odour.

\section{Material and methods}

\section{Fish material and treatments}

To achieve a wide variation in intrinsic raw material properties, we used free-living and farmed Atlantic salmon (Salmo salar, L) of different origin/geographic locations. The free-living salmon (ORS; $\mathrm{n}=105$ ) were transferred to open sea as farmed smolts and harvested as adults after return to Iceland (Kollafjordur) one year later. The farmed salmon (FS) were sampled at four different farms located at the Mid- or Northern coast of Norway (FS-a, FS-b, FS-c and FS-d; n=105/ fish group). FS-a and FS-d (AquaGen strain), and FS-c (Mowi strain) were commercially sea-cage reared salmon, and the mean starvation time before slaughtering was 16 days. FS-b included seven sub-groups ( $n=15 /$ sub-group) that differed in origin and rearing conditions as described by Gomez-Guillèn and others (2000). All farmed fish were fed standard commercial diets containing about 33\% crude fat. The salmon within FS-a were anaesthetised using $\mathrm{CO}_{2}$, otherwise clubbing was used. All fish were gill-cut and bled in iced seawater. The seawater temperature at slaughtering was $7-13^{\circ} \mathrm{C}$. After slaughtering the fish were gutted, packed on ice in standard Styrofoam boxes and kept at $3-4{ }^{\circ} \mathrm{C}$ before non-destructive fat determination by computerised X-ray 
tomography. Thereafter the fish were repacked on ice and shipped to France (IFREMER, Nantes) for processing. All salmon within FS-a and FS-b were processed after one-week of ice-storage. The free-living salmon and the farmed salmon within FS-c and FS-d were processed either after one week of ice-storage ( $n=75 /$ fish group) or after one month of frozen storage ( $\mathrm{n}=30$ / fish group) [frozen for 1 hour with cryogenic equipment $\left(\mathrm{CO}_{2}\right.$ at $\left.-60^{\circ} \mathrm{C}\right)$ and thereafter stored at $\left.-20^{\circ} \mathrm{C}\right]$. The fish were thawed in air at $+4^{\circ} \mathrm{C}$ for $24 \mathrm{~h}$ before processing. All fresh and frozen fish within the same group ( $\mathrm{n}=75$ fresh +30 frozen salmon/fish group) were processed simultaneously, enabled by different slaughtering time (Table 1).

Table 1. Sources of salmon used for calculation of weight losses during smoking processing, and analyses of raw and smoked fillets.

Weight loss due to processing

Trimming and filleting

Salting

Smoking

Analyses of raw fillets

Water and fat holding ability

Colorimetric analyses

Analyses of smoked fillets

Water and fat holding ability

Colorimetric analyses

Mechanical properties

Sensory analyses
Fish group*

ORS, FS-a, FS-b, FS-c, FS-d

ORS, FS-a, FS-b, FS-c, FS-d

ORS, FS-c, FS-d

ORS, FS-a, FS-b, FS-c, FS-d

ORS, FS-c, FS-d

ORS, FS-c, FS-d

ORS, FS-c, FS-d

ORS, FS-c, FS-d

FS-b

* See text for specification of abbreviations.

\section{Sources of salmon used for calculation of weight losses during processing}

Weight loss due to filleting and trimming was recorded for each fillet. The left fillet sides were kept raw, whereas a selection of randomly sampled right fillet sides were salted and smoked. Weight loss due to salting was recorded of 30 randomly sampled fresh fillets from each of ORS, FS-a, FS-c and FS-d, and of each frozen fillet within ORS, FS-c and FS-d (n=30/fish group). Each right fillet side within FS-b (n=105) was weighed before and after salting in order to calculate weight loss due to salting. Fish groups used for calculation of weight loss due to smoking included ORS, FS-c and FS-d. Fillets from these three fish groups were smoked at 20 or $30^{\circ} \mathrm{C}(15$ fresh and 15 frozen fillets at each smoking temperature/ fish group). Table 1 gives a summary of fish groups used for calculation of weight losses during smoking processing and analyses of quality characteristics of raw and smoked fillets. 


\section{Processing procedures}

Filleting and trimming were done by hand in an air-conditioned room $\left(12^{\circ} \mathrm{C}\right)$, by removing head, bones, fins and visible fat from the fillet surface. The left fillet sides were kept raw and stored at $-80^{\circ} \mathrm{C}$ until required for analyses of water and fat holding ability. The right fillet sides were dry salted (salt manufacturer: Salins du Midi, France) by hand and kept at $12^{\circ} \mathrm{C}$ for $6 \mathrm{~h}$, rinsed and kept at $2^{\circ} \mathrm{C}$ for another $12 \mathrm{~h}$ before smoking (skin on). The fillets were dried for 30 minutes at $20^{\circ} \mathrm{C}$ (humidity $65 \%$, air speed $2 \mathrm{~m} / \mathrm{s}$ ). The smoke was generated (auto combustion) from dry chips of beech and the smoking duration was 2.5 hours.

Calculation of the losses:

Loss in the production of trimmed fillets $(\%)=100 \times(\mathrm{GW}-\mathrm{TFW}) / \mathrm{GW}$.

Weight loss during salting $(\%)=100 \times($ TFW-SFW $) / T F W$.

Weight loss during smoking $(\%)=100 \times($ SFW-SW)/SFW.

Where GW = gutted weight; TFW = weight of trimmed fillets; SFW = weight of salted fillets; SW = weight of smoked fillets.

Fillet shape was calculated as $100 *$ Fillet weight (grams)/ fillet length $(\mathrm{cm})^{2}$, termed

\section{Fillet mass index, FMI.}

Raw and smoked tail halves were individually vacuum-packed (Boulanger, France) and stored at $-80^{\circ} \mathrm{C}$ until analyses of water and fat holding ability. One day before sensory sessions and mechanical analyses, the centre fillet parts were frozen (cryogenic method, Airgaz) for $20 \mathrm{~min}$ at $-60^{\circ} \mathrm{C}$ to an inner temperature of $-7^{\circ} \mathrm{C}$, and mechanically sliced (PNP, Tresses, France). Sliced fillets were immediately vacuumpacked and stored at $+2{ }^{\circ} \mathrm{C}$ until analysis.

\section{Analyses}

Analyses of raw fillet sides included colorimetric measurements (each left fillet side within ORS, FS-c and FS-d) and analyses of water and fat holding ability (236 randomly sampled left fillet sides from all fish groups). The smoked salmon fillets from ORS, FS-c and FS-d were subjected to colorimetric analyses (each smoked fillet), analyses of water and fat holding ability (19 randomly sampled fillets from all fish groups/ treatment) and mechanical properties (each smoked fillet). Sensory analyses were performed in the salmon within FS-b (smoking temperature $20^{\circ} \mathrm{C}$ ). Fig. 1 illustrates which parts of the salmon fillets were used for analyses. 
Figure 1. Illustration showing which parts the salmon fillets was used for analyses

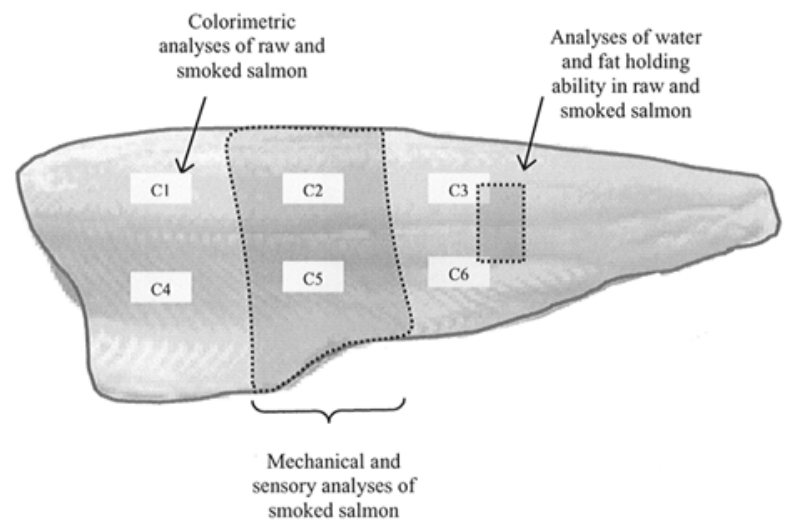

Fillet fat content was determined by computerised X-ray tomography (CT) within two days after slaughtering using a whole body scanner (Somatom 2 CT, Siemens, Germany), as described by Rye (1991). Fat distribution was estimated as the area of visualised fat deposited divided by the total scan area anterior to the dorsal fin (Rye and others 1995). Centrifugation test of water and fat holding capacity was performed in triplicate in raw and smoked fillets according to Gomez-Guillen and others (2000). Mechanical measurements were performed using a Traction-compression machine from Lloyd Instrument (LRX 50, Montigny le Bretonneux, France) assembled with a Kramer shear-cell (10 blades, $11 \times 7 \mathrm{~cm}$ ). The force needed to cut through smoked slices ( $5 \mathrm{~cm}$ x $6 \mathrm{~cm} \times 2.5 \mathrm{~mm}$ ) perpendicular to the myotomes was recorded in 2 slices per smoked fillet (45 fillets in total/ processing treatment). The test speed was 60 $\mathrm{mm} / \mathrm{min}$. Colorimetric measurements were made with a Hunterlab miniscan XE (Reston, Virginia, USA) using the light source D65 and $10^{\circ}$ observer angle, and L* (lightness), a* (redness) and b* (yellowness) values (CIE 1976) were recorded in raw fillets immediately after filleting and in smoked fillets after they were withdrawn from the smoking-oven (45 fillets in total/ processing treatment; six measurements per fillet).

Sensory analyses were performed in smoked salmon from FS-b. The sensory panel consisted of 20 panellists trained to describe fish products with the AFNOR method (NF ISO 8586-1, 1993). Each panellist received two slices per fillet from the area beneath the dorsal fin ( $2.5 \mathrm{~mm}$ thick) from four out of the seven different fish groups (randomly). To replicate analyses, the sensory assessments were performed at 8, 9, 12 and 13 days after smoking. Samples were evaluated using profiling test (incomplete block experimental design). The sensory attributes included in the evaluation were: smoke intensity odour, wood fire odour, smoke intensity flavour, wood fire flavour, pink colour, white striation, fatty aspect (presence of fatty droplets on the surface), firmness (force needed to crunch the product after first bit), melting texture (feeling of disappearing of the product), pasty texture (paste-like behaviour during chewing) and fatty texture (feeling of fat in the mouth). Results on each characteristic are given as means for each of the seven fish groups. Sessions were performed in individual partitioned booths equipped with a computerised system (Fizz system, Biosystemès, 
Dijon). These conditions were conductive to concentration and avoided communication between panellists and disturbance by external factors (NF V-09-105, 1995). The panellists rated the sensory attributes on a continuous scale presented on a computer screen, from low intensity (0) to high intensity (10). Products were assigned 3-digit numbers, randomised and served simultaneously.

\section{Statistics}

Experimental data were analysed by regression, correlation (Pearson's correlation coefficient) or variance analyses with significance defined at $\mathrm{p}<0.05$. Only significant correlations are reported. Significant differences between mean values were determined by least significant differences. All statistical analyses were performed with the Statistical Analysis System (SAS Institute Inc., Cary, N.C., U.S.A.).

\section{Results and discussion}

A high variation was found in fat content, visible fat deposits and fillet shape (Table 2 and Figure 2). The average fat content was higher in the farmed salmon (17.4\%, sd $2.9 \%)$ than in the free-living salmon (9.4\%, sd 2.8\%), and visible fat amounted to nearly twice as much of the cross sectional cutlet area of the farmed salmon (8.1\%, sd 2.3) compared with the free-living salmon (4.3\%, sd 0.9). The correlation between fat content and visible fat deposits within each fish group was: $r=0.7-0.8$. The fillet mass index (FMI) averaged $44.5 \mathrm{~g} \mathrm{~cm}^{-2}$ (sd 3.9) and $47.7 \mathrm{~g} \mathrm{~cm}^{-2}$ (sd 4.8) for the freeliving and farmed salmon, respectively. FMI showed no systematic relationship with fat content. The results thus indicate that fat content in salmon fillets cannot be predicted from the fillet shape. The mean fat content and visible fat deposits of the sub-groups within FS-b ranged from 12.4 to $17.9 \%$ and from 5.0 to $7.9 \%$, respectively, and the range in FMI was 45.3 to $51.1 \mathrm{~g} \mathrm{~cm}^{-2}$.

Table 2. Mean values for gutted weight, fillet shape, fat content and area of visible fat deposits for the Atlantic salmon groups used in the study. Different letters indicate significant differences between fish groups $(p<0.05)$.

\begin{tabular}{|c|c|c|c|c|c|c|c|c|}
\hline \multirow[b]{2}{*}{$\begin{array}{l}\text { Fish group } \\
\text { Sampling period/ } \\
\text { parameter }\end{array}$} & \multicolumn{2}{|c|}{$\frac{\text { Free-living salmon }}{\text { ORS }}$} & \multicolumn{6}{|c|}{ Farmed salmon } \\
\hline & $\begin{array}{c}\text { O) } \\
\begin{array}{c}\text { July } 1998 \\
\text { frozen } \\
n=30\end{array} \\
\end{array}$ & $\begin{array}{l}\text { July } 1998 \\
\text { fresh } \\
n=75 \\
\end{array}$ & $\begin{array}{c}\text { FS-a } \\
\text { Oct } 1997 \\
\text { fresh } \\
n=105 \\
\end{array}$ & $\begin{array}{c}\text { FS-b } \\
\text { Jan } 1998 \\
\text { fresh } \\
\mathrm{n}=105 \\
\end{array}$ & $\begin{array}{c}\text { FS } \\
\text { Oct } 1998 \\
\text { frozen } \\
n=30 \\
\end{array}$ & $\begin{array}{l}\text { Nov } 1998 \\
\text { fresh } \\
n=75 \\
\end{array}$ & $\begin{array}{r}\text { FS } \\
\begin{array}{c}\text { Apr } 1999 \\
\text { frozen } \\
n=30\end{array} \\
\end{array}$ & $\begin{array}{l}\text { May } 1999 \\
\text { fresh } \\
n=75 \\
\end{array}$ \\
\hline Gutted weight, kg & 2.6 & 2.6 & 4.1 & 3.4 & 3.9 & 4.0 & 4.0 & 3.6 \\
\hline Fillet mass index* & $42.8^{\mathrm{c}}$ & $44.7^{b}$ & $49.7^{\mathrm{a}}$ & $48.1^{\mathrm{a}}$ & $44.1^{\mathrm{bc}}$ & $49.2^{\mathrm{a}}$ & $48.1^{\mathrm{a}}$ & $43.6^{\mathrm{bc}}$ \\
\hline Fillet fat content, $\%$ & $8.5^{\mathrm{g}}$ & $9.8^{\mathrm{f}}$ & $17.9^{\mathrm{c}}$ & $14.5^{\mathrm{e}}$ & $21.8^{\mathrm{a}}$ & $19.4^{\mathrm{b}}$ & $16.7^{\mathrm{d}}$ & $16.8^{d}$ \\
\hline Area of fat depots, $\%$ & $4.0^{f}$ & $4.4^{\mathrm{f}}$ & $7.1^{\mathrm{d}}$ & $6.2^{\mathrm{e}}$ & $12.4^{\mathrm{a}}$ & $10.2^{\mathrm{b}}$ & $8.2^{\mathrm{c}}$ & $7.8^{\mathrm{c}}$ \\
\hline
\end{tabular}

* Fillet mass index $=100 *$ Fillet weight $(\mathrm{g}) /$ fillet length $(\mathrm{cm})^{2}$ 
Figure 2. Distribution of ${ }^{\text {A) }}$ Fat content, ${ }^{\mathrm{B})}$ Amount of visible fat deposits, and ${ }^{\mathrm{C})}$ Fillet mass index in the farmed $(n=420)$ and free-living $(n=105)$ salmon.

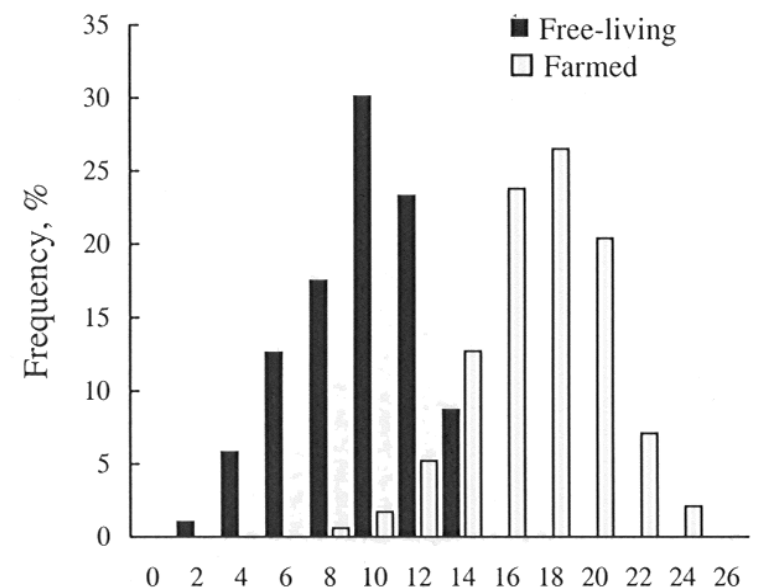

A

Fillet fat content, \%
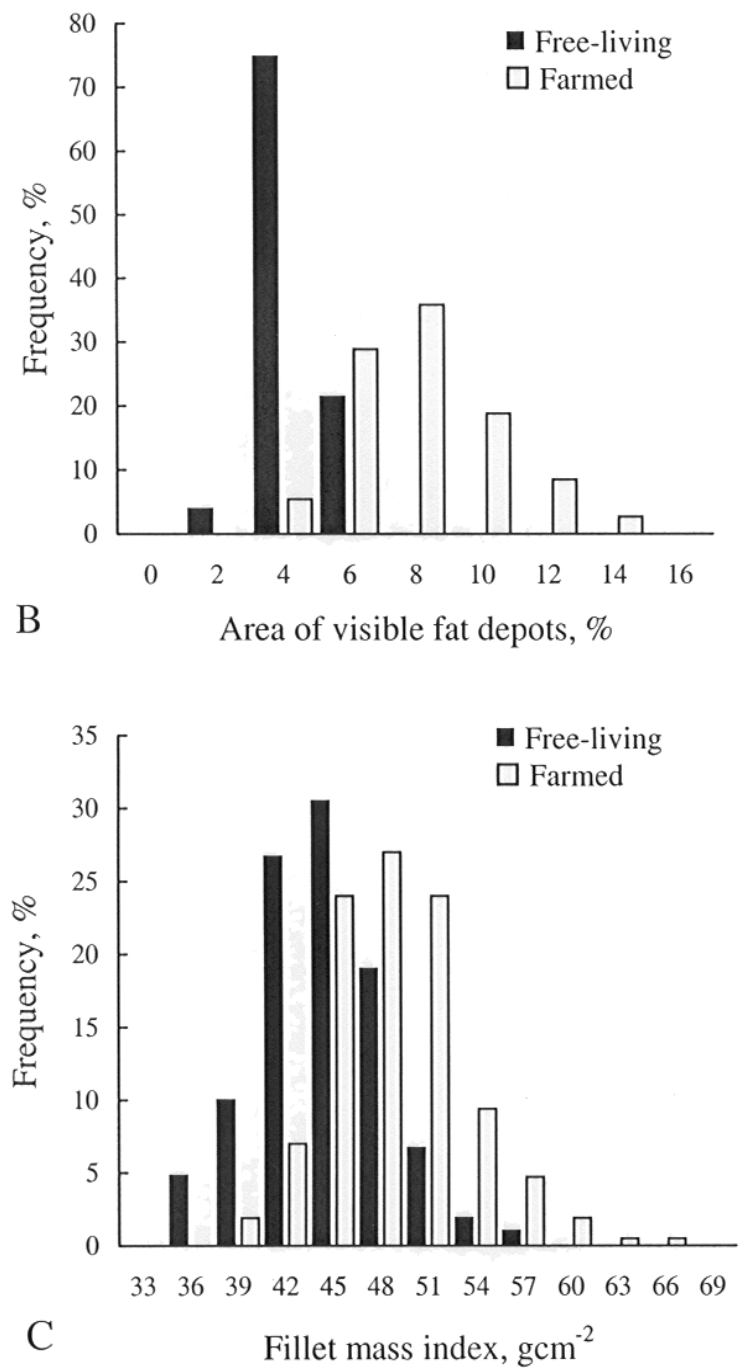


\section{Product loss during smoking processing}

\section{Weight loss due to filleting and trimming}

Weight loss due to filleting and trimming ranged from $30-45 \%$ (37.5\% on average), but visible fat deposits and fat content only explained 3.3\% and $1.2 \%$ of this variation, respectively. Within fish groups, only the visible fat deposits of the FS-c correlated significantly with filleting and trimming loss $(r=0.24)$. The results thus indicate that the fat content itself only has a minor impact on weight loss in the production of trimmed fillets, provided that the fat is evenly distributed in the flesh.

Increasing FMI coincided with decreasing loss in the production of trimmed fillets. For two of the farmed fish groups (FS-c and FS-b), variations in FMI explained $25 \%$ of the weight loss due to filleting and trimming, whereas the overall correlation was $r=-0.20$. Previous studies have likewise reported that higher body mass attributes to higher fillet yield, probably due to a lower proportion of head, bones and fins in fish with a voluminous body shape (Bosworth and others 1998; Einen and others 1999). No overall correlation was found between gutted weight and weight loss due to filleting and trimming.

\section{Weight loss due to salting}

Weight reduction due to salting was $5.3 \%$ on average, with no significant differences between ice and frozen stored salmon. Increasing fat content coincided with decreasing weight loss (Fig 3), but regression analyses revealed that both fillet weight $(p=0.0001)$ and fat content $(p=0.0001)$ had a significant impact on weight loss due to salting. Fat and water content are inversely related in adult immature salmon, adding up to about $80 \%$ of the muscle weight (Aursand and others 1994; Shearer 1994). The lower weight loss from the fatter fillets may thus attribute to less amounts of water available for transfer due to the osmotic gradient produced by salting. Adjusting the salting method according to fillet composition and fish size may, according to the present results, increase the certainty of predicting the salt concentration of the final product. The calculated FMI only explained $2-4 \%$ of the overall variation in weight loss due to salting. 
Figure 3. Weight loss due to dry salting in relation to fat content in Atlantic salmon fillets $(n=315)$. Salmon processed following ice-storage are indicated by open symbols. Salmon frozen prior to processing are indicated by full symbols.

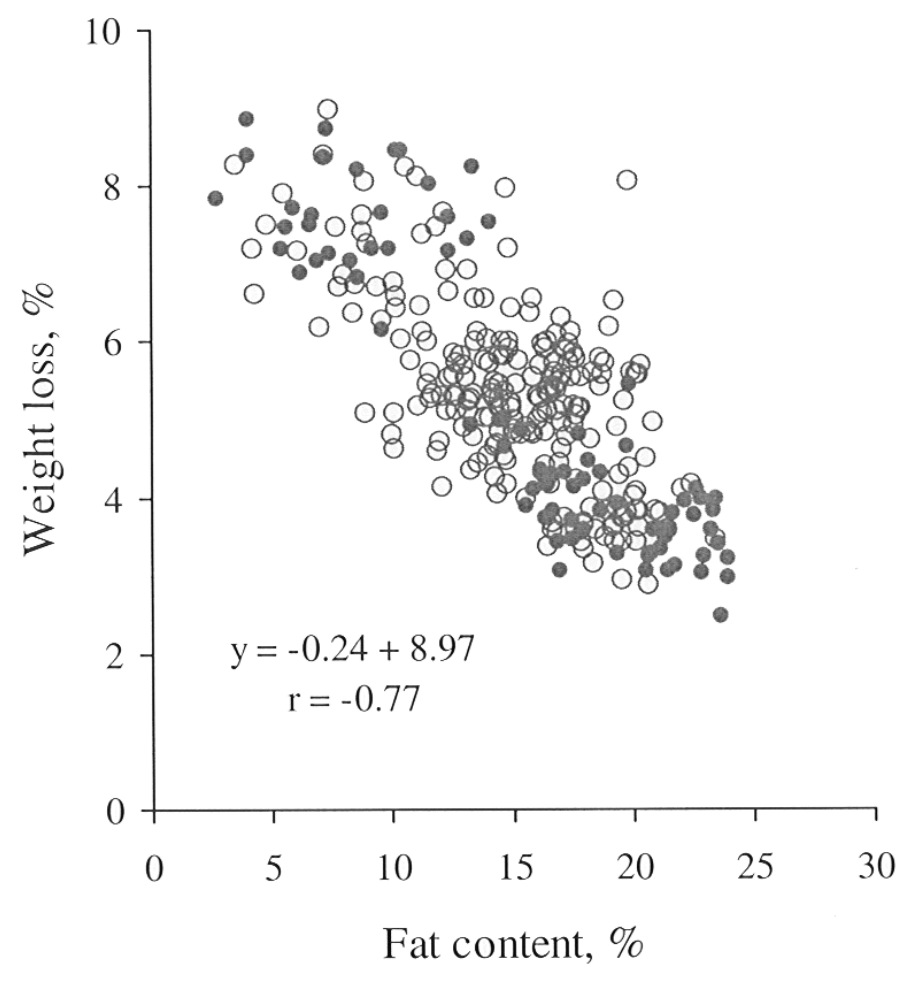

Weight loss due to smoking

The smoking related loss averaged 6.8-7.1\% and 5.8-5.9\% for the fillets smoked at 20 and $30^{\circ} \mathrm{C}$, respectively, and no significant difference was observed between fresh and frozen stored material. The weight loss decreased with increasing fat content for the salmon frozen prior to processing at both $20^{\circ} \mathrm{C}(\mathrm{r}=-0.73)$ and $30^{\circ} \mathrm{C}(\mathrm{r}=-0.62)$ smoking temperature. However, for the salmon processed after one week of icestorage, only fillets smoked at $30^{\circ} \mathrm{C}$ showed negative correlation between fat content and weight loss due to smoking $(r=-0.39)$. Lower amounts of water available for dehydration from the fatter fillets, probably explains the negative correlation between fat content and weight loss due to smoking. The more pronounced relationship between fat content and weight loss for the frozen stored salmon may be due to denaturation caused by freezing, and hence lower water binding ability when exposed to heating.

\section{Water loss from raw and smoked muscle}

Water loss from raw muscle averaged 18.4\% (range 6 - 37\%). The ice-stored salmon showed no correlation between raw material characteristics and water loss, but water loss from the frozen stored salmon correlated negatively to fat content/ visible fat deposits $(r=-0.2$ to $r=-0.5)$. Water loss from smoked salmon increased with 
increasing fat content and visible fat deposits within all treatments, except from the frozen-stored salmon smoked at $30^{\circ} \mathrm{C}$, where only the farmed salmon showed increasing water loss with increasing fat content/ visible fat deposits (Fig 4). Overall, visible fat deposits showed the most consistent and highest correlation with water loss of the smoked salmon.

In white muscle of salmon, most of the fat is deposited in the connective tissue surrounding muscle bundles (Aursand and others 1994). According to Ofstad and others (1993), collagen begins to swell and denature at $20^{\circ} \mathrm{C}$. Melting of collagen, sufficient to alter the physical barrier to release of fluid, may thus have contributed to the positive correlation between fat deposition and water loss from the smoked muscle. Ofstad and others (1993) suggested that liquid loss upon heating might be affected by the distribution of extra and intracellular fat. Our results indicate that salmon flesh rich in pure adipose tissue is more susceptible to subsequent water loss.

Figure 4. Water loss in relation to fat content from free-living (ORS) and farmed (FS) dry salted Atlantic salmon smoked at either $20^{\circ} \mathrm{C}$ or $30^{\circ} \mathrm{C}$. Salmon processed following ice storage are indicated by open symbols. Salmon frozen prior to processing are indicated by full symbols.
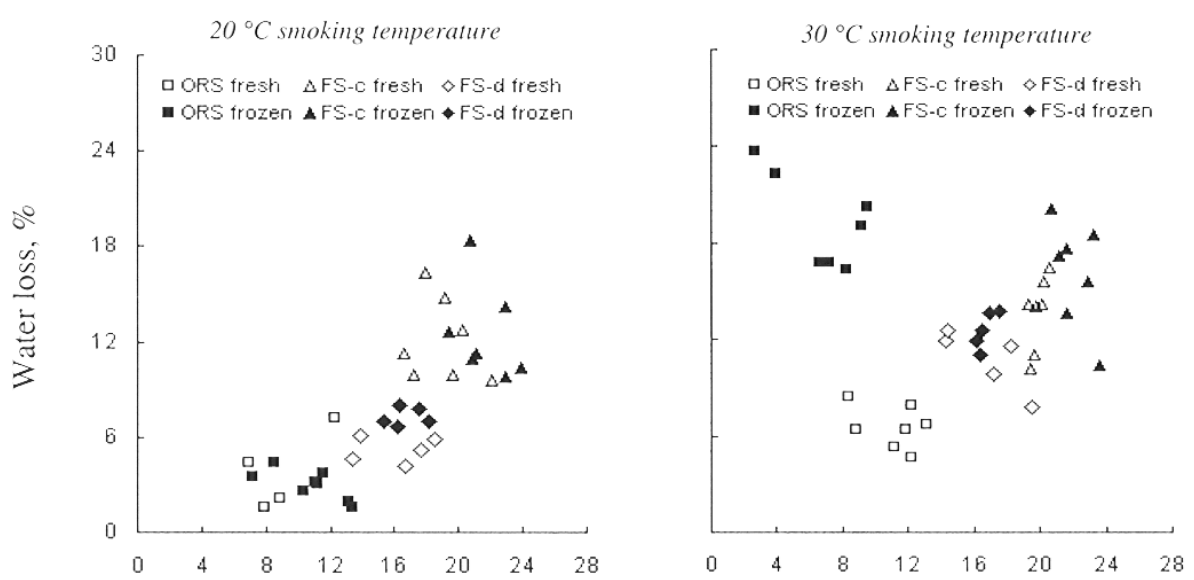

Fat content, \%

\section{Fat release from raw and smoked muscle}

Fat release from raw muscle ranged from 2 to $18 \%$, with an average of $6.5 \%$. Variation in fat content and visible fat deposits explained $44 \%$ and $55 \%$ of the overall variation in fat release, respectively. The slope of the regression line was, however, largely determined by the results of the salmon slaughtered during autumn 1998 (FSc), which had a high fat content coinciding with high fat release (Fig 5).

Bell and others (1998), found no appearance of fat release from salmon flesh with fat content $<12 \%$. Hence, there appears to be a certain relationship between fat release and fat content above a given fat threshold value. Bell and others (1998) moreover observed higher appearance of oil exudation from the flesh during late autumn at which time the FS-c was slaughtered. Yet, the implied seasonality seems ambiguous as the salmon slaughtered in October 1997 (FS-a) showed no elevated fat release. At a 
$15 \%$ fat level, visible fat deposits amounted to $8.4 \%$ of the cross sectional cutlet area within the FS-c and 5.5\% within the FS-a. Therefore, the potential of fat release may owe to a multitude of interrelated factors, where fat content, amount of fat deposits and seasonal variations are included. As for the raw salmon, fat release from the smoked salmon was significantly highest for the FS-c. Thus, fat release for the smoked salmon showed similar positive correlations with fat content as was observed for the raw salmon. No relationship was found between fat release and fillet weight or fillet shape.

Figure 5. Fat release from raw muscle of Atlantic salmon in relation to ${ }^{\mathrm{A})}$ fat content $\left(\mathrm{Y}=0.04 \mathrm{x}^{2}-0.85 \mathrm{x}+7.93\right)$ and ${ }^{\mathrm{B})}$ amount of visible fat deposits $\left(\mathrm{Y}=0.12 \mathrm{x}^{2}-1.03 \mathrm{x}\right.$ + 6.68) $(\mathrm{n}=236)$. Results from salmon slaughtered autumn $1998(\mathrm{FS}-\mathrm{c})$ are indicated by open symbols

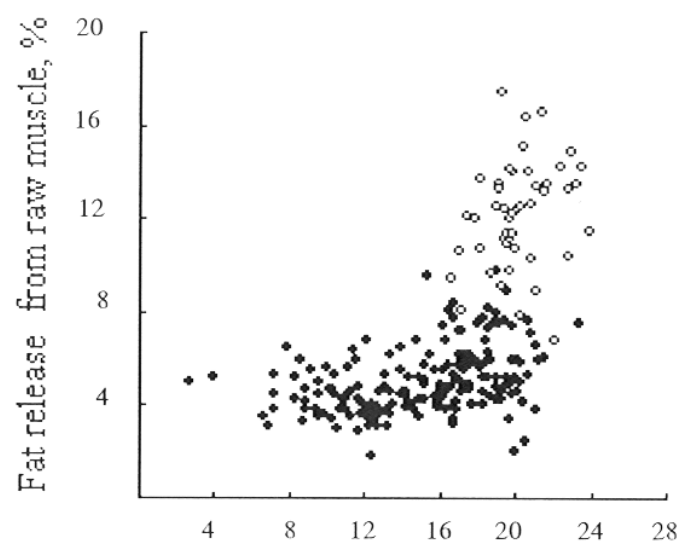

Fat content, \%

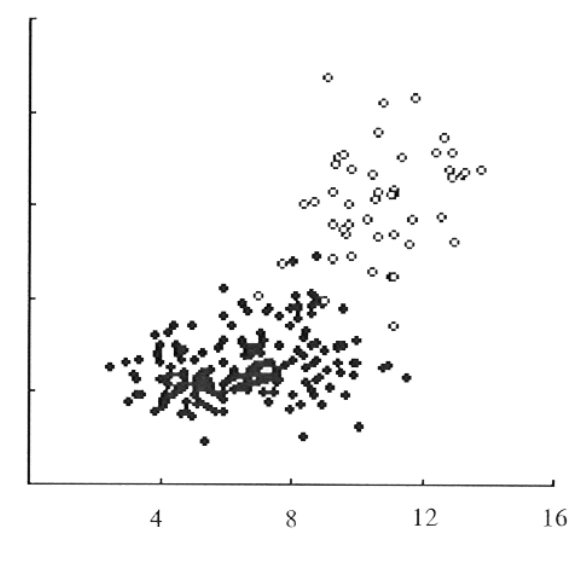

Visible fat depots, area\%

\section{Mechanical properties of smoked salmon}

Shear-force measured in the ice-stored salmon was relatively stable around $89 \mathrm{~N}$, with no significant correlation with raw material characteristics. However, for the farmed frozen stored salmon, shear-force decreased with increasing fat content at both $20^{\circ} \mathrm{C}$ (76 $\mathrm{N}$ on average; $\mathrm{r}=-0.46)$ and $30^{\circ} \mathrm{C}(70 \mathrm{~N}$ on average; $\mathrm{r}=-0.27)$ smoking temperature. The frozen stored free-living salmon also showed decreasing shear-force with increasing fat content at $30^{\circ} \mathrm{C}(52 \mathrm{~N}$ on average; $r=-0.46)$ but not at $20^{\circ} \mathrm{C}$ smoking temperature (92 $\mathrm{N}$ on average). Visible fat deposits showed similar correlations with shear-force as the fat content. Previous results with Atlantic salmon are contradicting regarding the relationship between fat content and mechanical properties (Andersen and others 1997; Gomez-Guillin and others 2000), but our results suggest that the effect of fat content on shear-force is more pronounced in smoked salmon frozen prior to processing than in salmon that is processed following ice-storage. 


\section{Colorimetric measurements of raw and smoked salmon.}

In raw ice-stored salmon, increasing fattiness coincided with increasing $\mathrm{L}^{*}$-values $(\mathrm{r}=$ $0.42-0.62)$ and $b^{*}$-values $(r=0.42-0.58)$, but the $a^{*}$-values and fat content were not correlated. The frozen stored salmon showed no correlation between colorimetric measurements and fat content. The smoked salmon had lower $\mathrm{L}^{*}$ and $\mathrm{a}^{*}$-values, and higher $\mathrm{b}^{*}$-values compared with raw salmon (Table 3 ). The ice stored salmon displayed higher change due to smoking in $\mathrm{L}^{*}$-values, and lower change of $\mathrm{a}^{*}$ - and $b^{*}$-values with increasing fat content. The change in $\mathrm{L}^{*}, \mathrm{a}^{*}$ and $\mathrm{b}^{*}$-values of the frozen stored salmon showed no correlation with raw material characteristics. The final smoked fillets showed increasing $\mathrm{L}^{*}, \mathrm{a}^{*}$ and $\mathrm{b}^{*}$-values with increasing fat content within all treatments and fish groups. The average correlations between fat content and the $L^{*}, a^{*}$ and $b^{*}$-values of the smoked salmon were $r=0.55, r=0.72$ and $r=0.78$, respectively. Visible fat deposits showed less pronounced relationship with colorimetric measurements than total fat content.

Several authors have likewise reported significant interactions between fat content and the perceived colour of raw and smoked salmon (Christiansen and others 1995; Wathne 1995; Rørå and others 1998; Einen and Skrede 1998). However, from our results it appears that freezing prior to processing diminishes the effect of fat content on the optical properties of raw salmon, and that changes in colour characteristics from raw to smoked products is affected by variations in fat content only when fresh material is used.

Table 3. Mean values \pm standard error for $\mathrm{L}^{*}$-values (lightness), $\mathrm{a}^{*}$-values (redness) and $b^{*}$-values (yellowness) in raw and smoked salmon fillets. The salmon were processed either after one-week of ice-storage or after one month of frozen storage. The smoking temperature was $20^{\circ}$ or $30^{\circ} \mathrm{C}$ (raw salmon: $\mathrm{n}=90$ for fresh and frozen salmon, respectively; smoked salmon: $n=45$ for each treatment).

\begin{tabular}{lccc}
\hline & $\begin{array}{c}\mathrm{L}^{*} \text {-value } \\
\text { mean } \pm \mathrm{SE}\end{array}$ & $\begin{array}{c}\mathrm{a}^{*} \text {-value } \\
\text { mean } \pm \mathrm{SE}\end{array}$ & $\begin{array}{c}\mathrm{b}^{*} \text {-value } \\
\text { mean } \pm \mathrm{SE}\end{array}$ \\
\hline \hline $\begin{array}{l}\text { Raw salmon fillets } \\
\text { fresh }\end{array}$ & $54.3 \pm 0.16$ & $25.5 \pm 0.14$ & $22.1 \pm 0.12$ \\
frozen & $55.5 \pm 0.31$ & $26.2 \pm 0.31$ & $23.6 \pm 0.27$ \\
& & & \\
$\begin{array}{l}\text { Smoked salmon fillets } \\
\text { fresh } 20^{\circ} \mathrm{C}\end{array}$ & $48.3 \pm 0.25$ & $21.3 \pm 0.37$ & $26.5 \pm 0.40$ \\
fresh $30^{\circ} \mathrm{C}$ & $51.0 \pm 0.33$ & $19.9 \pm 0.37$ & $29.9 \pm 0.37$ \\
frozen $20^{\circ} \mathrm{C}$ & $47.7 \pm 0.39$ & $23.2 \pm 0.40$ & $28.6 \pm 0.34$ \\
frozen $30^{\circ} \mathrm{C}$ & $52.4 \pm 0.40$ & $21.5 \pm 0.28$ & $33.0 \pm 0.28$ \\
\hline
\end{tabular}

\section{Sensory characteristics}

Smoke intensity flavour and wood fire flavour correlated positively with fat content (Fig. 6) and visible fat deposits ( $\mathrm{r}=0.89$ and $\mathrm{r}=0.82$, respectively), possibly because specific smoke-flavour related components are lipid-soluble. The particular nonpolarity of pure adipose tissue, may in consequence explain the somewhat higher 
correlation's found between the flavour properties and visible fat deposits. No correlation was found between fat content and deterioration flavour, which may attribute to the short storage period, so that not enough fatty acid oxidation had taken place to be detected by the sensory panel.

Neither colour, fatty aspect, white striation nor odour-attributes correlated significantly with fat content or visible fat deposits. These results are in contradiction with previous studies where the smoke odour weakened (Einen and Skrede 1998) and colour tone became more yellowish with increasing fat level (Einen and Skrede 1998; Einen and others 1999). Rørå and others (1998), however, found no relationship between fat content and the perceived colour or odour of smoked salmon. Scores for fatty texture correlated significantly with fat content (Fig. 6) and visible fat deposits (r $=0.80$ ), but the present study revealed no correlation between fat content and sensory score for firmness, melting- or pasty texture.

Figure 6. Smoke intensity flavour, wood fire flavour and fatty texture of smoked Atlantic salmon in relation to fat content (ordinary least square fit). Included are regression equations. Each point represents means of 15 salmon.
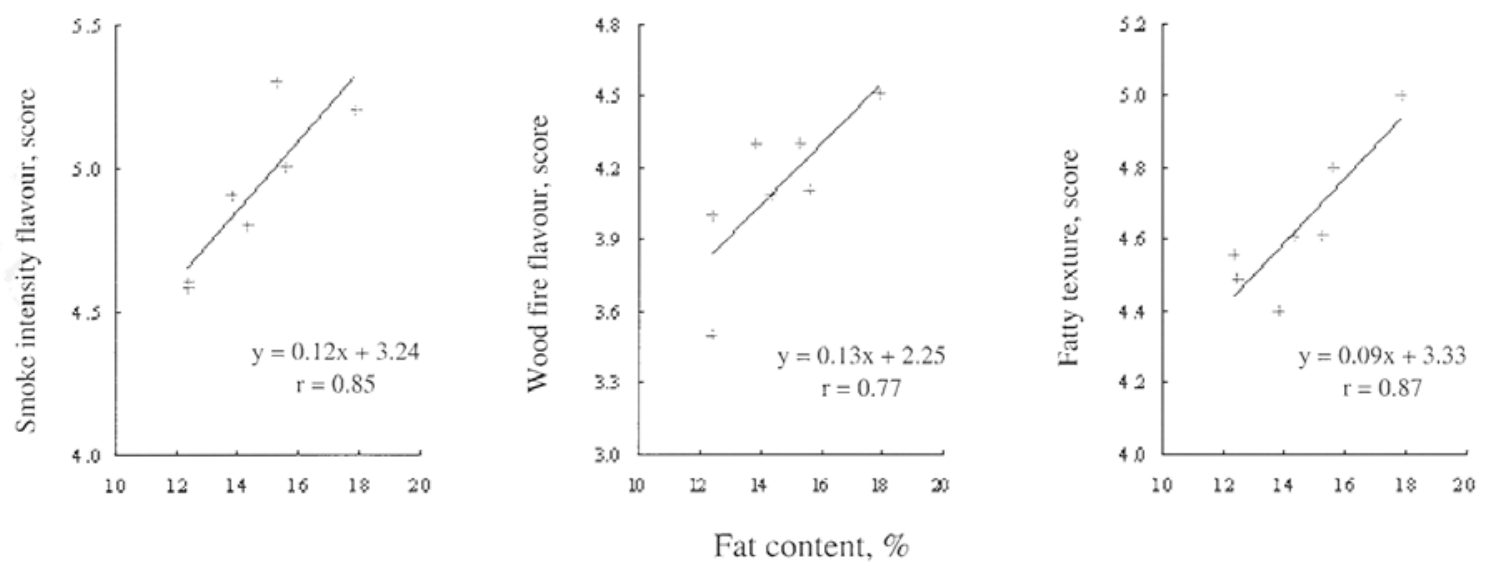

\section{Conclusion}

This study revealed that fat level and the amount of visible fat deposits interact with a series of other important product characteristics, i.e. processing yield, water and fat holding capacity, colour, texture and flavour. On-line evaluation of fat content or sorting salmon in groups with similar fat content would accordingly provide the possibility to better predict processability and quality of the final product. Grading according to fat content would moreover make it possible to adjust processing procedures according to raw material composition, thus meeting customers demand for specific quality properties. The present results moreover suggest that production yield of Atlantic salmon could be increased by selecting voluminous rather than slim salmon for processing. 


\section{Acknowledgement}

The EU under project FAIR CT-95-1101 financed this research. The authors thank the project coordinator Dr H. Hafsteinsson (Technological Institute of Iceland, Reykjavik, Iceland), Dr A.J. Borderias and Dr O. Einen for valuable comments on the manuscript.

\section{References}

Aursand M, Bleivik B, Rainuzzo JR, Jørgensen L, Mohr, V. 1994. Lipid distribution and composition of commercially farmed Atlantic salmon (Salmo salar). J. Sci. Food Agric. 64: 239-248.

Bell JG, McEvoy J, Webster JL, McGhee F, Millar RM, Sargent JR. 1998. Flesh lipid and carotenoid composition of Scottish farmed salmon (Salmo salar). J. Agric. Food Chem. 46: 119-127.

Bjerkeng B, Refstie S, Fjalestad KT, Storebakken T, Rødbotten M, Roem AJ. 1997. Quality parameters of the flesh of Atlantic salmon (Salmo salar) as affected by dietary fat content and full-fat soybean meal as a partial substitute for fish meal in the diet. Aquaculture 157: 295-307.

Borch OD, Aker H. 1997. Markedsdifferensiert produktkvalitet i lakseoppdrett. NF report no. 6, Nordland Research Institute, Bodo, Norway.

Bosworth BG, Libey GS, Notter DR. 1998. Relationships among total weight, body shape, visceral components, and fillet traits in palmetto bass (striped bass female Morone saxatilis x white bass male $M$. chrysops) and paradise bass (striped bass female $M$. saxatilis x yellow bass male $M$. mississippiensis). J. World Aquacult. Soc. 29: 40-50.

Christiansen R, Struksnaes G, Estermann R, Torrissen OJ. 1995. Assessment of flesh colour in Atlantic salmon, Salmo salar L. Aquacult. Res. 25: 311-321.

Einen O. 1998. Product quality in Atlantic salmon. Influence of dietary fat level, feed ration and starvation before slaughter. Doctor Scientarium Theses 1998:27, Agricultural Univ. Norway. 155p.

Einen O, Skrede G. 1998. Quality characteristics in raw and smoked fillets of Atlantic salmon (Salmo salar) fed high energy diets. Aquacult. Nutr. 4: 99-108.

Einen O, Mørkøre T, Rørå AMB, Thomassen MS 1999. Feed ration prior to slaughter - a potential tool for managing product quality of Atlantic salmon (Salmo salar). Aquaculture 178: 149-169.

Fiskeridirektoratet 1999. Havbruksavdelingen. Nøkkeltall fra Norsk Havbruksnæring, 13pp 
Gjedrem T. 1997. Flesh quality improvement in fish through breeding. Aquacult. Int. 5: 197-206.

Gomez-Guillen MC, Montero P, Hurtado O, Borderias AJ. 2000. Biological characteristics affect the quality of farmed Atlantic salmon and smoked muscle. J. Food Sci. 65: 53-60.

Gormley TR. 1992. A note on consumer preference of smoked salmon colour. Irish J. Agric. Food Res. 31: 199-202.

Haard NF. 1992. Control of chemical composition and food quality attributes of cultured fish. Food Res. Int. 25: 289-307.

Hillestad M, Johnsen F, Austreng A, Åsgård T. 1998. Long-term effects of dietary fat level and feeding rate on growth, feed utilization and carcass quality of Atlantic salmon. Aquacult. Nutr. 4: 89-97.

Koteng A. 1992. Markedsundersøkelse, norsk laks. Published by Fiskerinaeringens Landsforening, Bergen, Norway, 165 pp.

Ofstad Lie Ø, Huse I. 1992. The effect of starvation on the composition of Atlantic salmon (Salmo salar). Fis. Dir. Skr. Ser, Ernaer. 5: 1-11.

Lie Ø, Waagbø R, Sandnes K. 1988. Growth and chemical composition of adult Atlantic salmon (Salmo salar) fed dry and silage-based diets. Aquaculture 69: 343353.

NF ISO 8586-1 1993. General guidance for the selection, training and monitoring of assessors - Part 1: Selected assessors. In Contrôle de la qualité des produits alimentaires- Analyse sensorielle, AFNOR, Paris. P 75 - 97.

NF V-09-105 1995. Directives générales pour l'implantation de locaux destinés à l'analyse sensorielle. In Contrôle de la qualité des produits alimentaires- Analyse sensorielle, AFNOR, Paris. P 115 - 127.

R, Kidman S, Myklebust R, Hermansson A-M. 1993. Liquid holding capacity and structural changes during heating of fish muscle: cod (Gadus morhua L.) and salmon (Salmo salar). Food Structure 12: 163-174.

Rørå AMB, Kvåle A, Mørkøre T, Rørvik K.-A, Steien SH, Thomassen MS. 1998. Process yield, colour and sensory quality of smoked Atlantic salmon (Salmo salar) in relation to raw material characteristics. Food Res. Int. 31: 601-609.

Rye M. 1991. Prediction of carcass composition in Atlantic salmon by computerized tomography. Aquaculture 99: 35-48.

Rye M, Bæverfjord G, Jopson N. 1995. Computerized tomography can be used for evaluation of lipid distribution in market-sized Atlantic salmon. In Quality in aquaculture. Short communications and abstracts. European Aquaculture Society. Special publication 23: 387-388. 
Shearer KD. 1994. Factors affecting the proximate composition of cultured fish with emphasis on salmonids. Aquaculture 119: 63-88.

Sheehan EM, O’Connor TP, Sheehy PJA, Buckley DJ, FitzGerald R. 1996. The effect of dietary fat intake on the quality of raw and smoked salmon. Irish J. Agric. Food Res. 35: 37-42.

Torrissen OJ, Christiansen R, Struknæs G, Estermann R. 1995. Astaxanthin deposition in the flesh of Atlantic salmon, Salmo salar, L., in relation to dietary astaxanthin concentration and feeding period. Aquacult. Nutr. 1: 77-84.

Wathne E. 1995. Strategies for directing slaughter quality of farmed Atlantic salmon (Salmo salar) with emphasis on diet composition and fat deposition. Doctor Scientarium Thesis 1995:6, Agricultural Univ. Norway. 230p. 
07.12.05\CD JJFS 20001508 R1 
07.12.05\CD JJFS 20001508 R1 